UDC 577.112.7:616

\title{
ENDOPLASMIC RETICULUM-NUCLEI SIGNALING ENZYME-1 KNOCKDOWN MODULATES EFFECT OF HYPOXIA AND ISCHEMIA ON THE EXPRESSION OF CIRCADIAN GENES IN GLIOMA CELLS
}

\author{
L. L. Karbovskyi ${ }^{1}$, D. O. Minchenko ${ }^{1,2}$, \\ S. V. Danylovsky', M. Moenner, O. H. Minchenko ${ }^{1,3}$ \\ ${ }^{1}$ Palladin Institute of Biochemistry, NAS of Ukraine, 9, Leontovych St., Kyiv 01601, Ukraine \\ ${ }^{2}$ O. O. Bohomoletz National Medical University, 13, Shevchenko Boulvd., Kyiv 01601, Ukraine \\ ${ }^{3}$ INSERM U1029 Molecular Mechanisms of Angiogenesis Laboratory \\ University Bordeaux 1, Talence, France \\ e-mail: ominchenko@yahoo.com
}

The main molecular components of circadian clock system are proteins which play a significant role in the control of both metabolism and malignant tumor growth. Endoplasmic reticulum stress as well as hypoxia and ischemia are important factors for tumor neovascularization and growth. We have studied the expression of circadian genes in the glioma cell line U87 under knockdown of endoplasmic reticulum-nuclei-1 (ERN1) sensing and signaling enzyme. It was shown that blockade of ERN1 leads to increase in the expression levels of PER1, PER3 and CLOCK mRNA; but the CRY1, PER2, BMAL1, BMAL2 and DEC2 mRNA levels are decreased. Moreover, the expression levels of most of the studied genes are increased under glucose or glutamine deprivation conditions both in control and ERN1-deficient glioma cells; however knockdown of ERN1 modifies the effect of these ischemic conditions. Hypoxia has different effects on the expression levels of circadian genes and these effects are dependent on ERN1 function. Hypoxia induces the expression of PER1, BMAL1 and DEC2 and decreased - PER3, CLOCK, CRY1 and BMAL2 mRNA in control glioma cells, while in genetically modified cells it induces the expression of BMAL1 mRNA only. Thus, the expression of circadian genes is dependent on ERN1 signaling enzyme function in normal, hypoxic and ischaemic conditions.

Key words: mRNA expression, PER1, PER2, PER3, CLOCK, BMAL1, BMAL2, CRY1, DEC2, glioma cells, endoplasmic reticulum-nuclei-1 knockdown, hypoxia, glucose and glutamine deprivation.

\section{INTRODUCTION}

Circadian factors PER1, PER2, PER3, CLOCK, BMAL1, CRY1 and CRY2 are the main molecular components of the circadian clock system and play a significant role in 
control of both metabolism and malignant tumor growth [1-6]. The rapid growth of different solid malignant tumors generates micro-environmental changes in association to nutrient deprivation, hypoxia and acidosis $[7,8]$. Under those ischaemic conditions, cancer cells trigger an adaptive response and initiate the formation and attraction of new blood vessels inside the tumor. Hypoxia and ischemia as well as endoplasmic reticulum stress are the main factors which are necessary for tumor neovascularization and growth $[7,9]$. Ischemia and hypoxia have been shown to induce a set of complex intracellular signaling events known as the unfolded protein response, which is mediated by three sensor systems to adapt cells for survival or, alternatively, to enter cell death programs through endoplasmic reticulum-associated machineries [7, 10-13]. The endoplasmic reticulum-nuclei-1 signaling enzyme (also named by inositol requiring enzyme-1alpha) is a major sensor which controls hundreds of genes [14, 15]. As such, it participates in the early cellular response to the accumulation of misfolded proteins in the lumen of the endoplasmic reticulum, occurring under both physiological and pathological conditions.

Two distinct catalytic domains of the bifunctional signaling enzyme endoplasmic reticulum-nuclei-1 were identified: a serine/threonine kinase and an endoribonuclease which contribute to endoplasmic reticulum - nuclei-1 signalling. The endoplasmic reticulum-nuclei-1-associated kinase activity autophosphorylates and dimerizes this enzyme, leading to the activation of its endoribonuclease domain, degradation of a specific subset of mRNA and initiation of the pre-XBP1 (X-box binding protein 1) mRNA splicing $[14,16]$. Mature XBP1 mRNA splice variant encodes a transcription factor that has a different $\mathrm{C}$-terminus amino acid sequence and stimulates the expression of hundreds of unfolded protein response-specific genes [16, 17].

Recently the endoplasmic reticulum-nuclei-1 gene was proposed as a major contributor to tumor progression among protein kinases because single mutations were detected in different human cancers and encoded by this gene enzyme [18]. Moreover, the growing tumor requires the endoplasmic reticulum stress for own neovascularization and growth and the complete blockade of endoplasmic reticulum - nuclei-1 signal transduction pathway has anti-tumor effects [7, 9]. The endoplasmic reticulum stress response-signalling pathway is linked to the neovascularization process, tumor growth and differentiation, and cell death processes [8, 9].

Circadian clock system controls the cell proliferation process and carcinogenesis, thus circadian proteins PER1, PER2, CLOCK, BMAL1 and CRY1 function as tumor suppressors [19-21]. Therefore, the overexpression of the circadian gene PER1 or $P E R 2$ in cancer cells resulted in significant growth inhibition and in apoptosis. Circadian genes have an emerging role as key players in malignant transformation [21]. Deregulated expression of the PER1, PER2 and PER3 genes as well as inactivation or knockout PER2, PER1, CLOCK and BMAL1 leads to malignization, especially in the breast, as well as to the appearance of different disorders such as obesity [22-25]. A better understanding of the impact of circadian gene networks on cell cycle control as well as nutrient balance at the molecular, cellular and system levels promises to shed light on the emerging association between circadian timing and disorders of sleep, diabetes, obesity, and cancer.

In this study we have investigated the role of signaling enzyme endoplasmic reticulum-nuclei-1 in the expression of different circadian genes in the glioma cell line U87 for evaluation of circadian gene expression responsibility from this signaling enzyme function under hypoxic and ischemic (glucose or glutamine deprivation) conditions.

ISSN 1996-4536 • Біологічні Студії / Studia Biologica • 2011 • Том 5/№2 • С. 37-50 


\section{MATERIALS AND METHODS}

Cell Lines and Culture Conditions. The glioma cell line U87 was obtained from ATCC (U.S.A.) and grown in high glucose (4,5 g/l) Dulbecco's modified Eagle's minimum essential medium (Gibco, Invitrogen, USA) supplemented with glutamine (2 mM), $10 \%$ fetal bovine serum (Equitech-Bio,Inc., USA), penicillin (100 units/ml; Gibco) and streptomycin $\left(100 \mu \mathrm{g} / \mathrm{ml}\right.$; Gibco) at $37^{\circ} \mathrm{C}$ in a $5 \% \mathrm{CO}_{2}$ incubator. In this work we used two sublines of this glioma cell line. One subline has suppressed both protein kinase and endoribonuclease activities of sensor and signaling enzyme endoplasmic reticulum-nuclei-1, which was obtained by selection of stable transfected clones with overexpression of endoplasmic reticulum-nuclei-1 dominant/negative constructs (dnERN1) [13]. Second subline was obtained by selection of stable transfected clones with vector, which was used for creation of dnERN1. This subline was used as control 1. Control 2 represents U87 glioma cells overexpressed dominant-negative construct of endoplasmic reticulum-nuclei-1 (fig. 1).

Fig. 1. Effect of tunicamycin $(0.01 \mathrm{mg} / \mathrm{ml}$ during $2 \mathrm{hrs})$ on the expression of XBP1 and its splice variant $\left(\mathrm{XBP}_{\mathrm{s}}\right)$ in U87 glioma cells overexpressed dominant-negative construct of endoplasmic reticulum-nuclei-1 (ERN1-DN) and control glioma cells transfected with vector $(\mathrm{C})$

Рис. 1. Вплив тунікаміцину (0,01 мг/мл протягом 2 год) на експресію ХВР1 та його сплайс-варіанта $\left(\mathrm{XBP} 1_{\mathrm{s}}\right)$ у клітинах гліоми лінії U87 з надекспресією домінант-негативної конструкції ендоплазматичний ретикулум-ядро-1 (ERN1-DN) і контрольних клітинах гліоми, трансфекованих вектором (C)

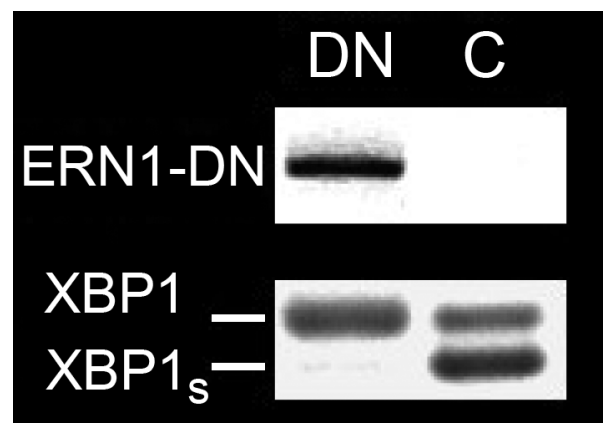

Full suppression of enzymatic activity of dnERN1 was estimated by the analysis of expression of XBP1 and its splice variant $\left(\mathrm{XBP}_{\mathrm{s}}\right)$ in U87 glioma cells that overexpress a dominant-negative construct of endoplasmic reticulum-nuclei-1 as compared to control glioma cells transfected with vector. As shown in fig. 1, inductor of endoplasmic reticulum stress tunicamycin strongly induced the alternative splicing of XBP1 only in control glioma cells.

Hypoxic conditions were created in special incubator with 3\% oxygen and $5 \%$ carbon dioxide levels and culture plates were exposed for $16 \mathrm{hrs}$. For glucose or glutamine deprivation the growing medium in culture plates was replaced with medium without glucose or glutamine and exposed for $16 \mathrm{hrs}$.

RNA isolation. Total RNA was extracted from different tumor tissues and normal tissue counterparts using Trizol reagent according to manufacturer protocol (Invitrogen, U.S.A.). RNA pellets were washed with $75 \%$ ethanol and dissolved in nuclease-free water.

Reverse transcription and quantitative PCR analysis. The expression levels of PER1, PER2, PER3, CLOCK, BMAL1, BMAL2, DEC2 and CRY1 mRNA were measured in the glioma cell line U87 and its subline with a deficiency of endoplasmic reticulum-nuclei-1 by quantitative polymerase chain reaction of complementary DNA (cDNA) using "Stratagene Mx 3000P cycler” (U.S.A.) and SYBRGreen Mix (AB gene, Great Britain). QuaniTect Reverse Transcription Kit (QIAGEN, Germany) was used for cDNA synthesis. Polymerase chain reaction was performed in triplicate. 
For amplification of PER1 (period 1) cDNA we used forward (5'-CACCCTGATGACCCACTCTT-3' and reverse (5'-GGTAAGGCTGGACTGGATGA-3') primers. The nucleotide sequences of these primers corresponds to sequences 3878-3897 and 4086-4067 of human PER1 cDNA (GenBank accession number NM_002616).

The amplification of PER2 (period 2) CDNA was performed using forward primer (5'-CGTGCCAAGCAGTTGACTTA-3') and reverse primer (5'-CAGCAAGGCTCAACAAATCA-3'). These oligonucleotides correspond to sequences 6000-6019 and 62076188 of human PER2 cDNA (GenBank accession number NM_022817).

The amplification of PER3 (period 3) cDNA for real time RCR analysis was performed using two oligonucleotides primers: forward - 5'-CGCTTCAGAACACACTTCCA-3' and reverse - 5'-TCATACCGTGCAGCTCTTTG-3'. The nucleotide sequences of these primers correspond to sequences 538-557 and 780-761 of human PER3 cDNA (GenBank accession number NM_016831).

Two other primers were used for real time RCR analysis of the expression of BMAL1 (aryl hydrocarbon receptor nuclear translocator-like, ARNTL1) cDNA: forward - 5'-AGTAGGTCAGGGACGGAGGT-3' and reverse - 5'-CACACAGGAAGCCCTCTAGC-3'. The nucleotide sequences of these primers correspond to sequences 41-60 and 262243 of human BMAL1 cDNA (GenBank accession number NM_001178).

For amplification of BMAL2 (ARNTL2) cDNA we used forward (5'-GAGTCCAGGGACAAGACCAA-3' and reverse (5'-CTCCTCCGCTTTTCAGTTTG-3') primers. The nucleotide sequences of these primers correspond to sequences 105-124 and 377-358 of human BMAL2 cDNA (GenBank accession number NM_020183).

For amplification of CLOCK cDNA we used forward (5'-AGGTTTGATCACAGCCCAAC-3' and reverse (5'-TATCATGCGTGTCCGTTGTT-3') primers. The nucleotide sequences of these primers correspond to sequences 1605-1624 and 1949-1930 of human CLOCK cDNA (GenBank accession number NM_004898).

For real time RCR analysis of CRY1 (cryptochrome 1, photolyase-like) cDNA expression we used next primers: forward - 5'-TTGCTTGATGCAGATTGGAG-3' and reverse - 5'-TTTTGCAGGGAAGCCTCTTA-3'. The nucleotide sequences of these primers correspond to sequences 2012-2031 and 2185-2166 of human CRY1 cDNA (GenBank accession number NM_004075).

For amplification of DEC2 (basic helix-loop-helix family, member e41; BHLHE41) cDNA we used forward (5'-GAGCATGAAACGAGACGACA-3' and reverse (5'-GATCGCTCCCCATTCTGTAA-3') primers. The nucleotide sequences of these primers correspond to sequences 393-412 and 647-626 of human DEC2 cDNA (GenBank accession number NM_030762).

The amplification of beta-actin cDNA was performed using primers: forward $-5^{\prime}-$ CGTACCACTGGCATCGTGAT-3' and reverse - 5'-GTGTTGGCGTACAGGTCTTT-3'. The expression of beta-actin mRNA was used as control of analyzed RNA quantity. The primers were received from "Sigma" (USA).

An analysis of quantitative PCR was performed using special computer program "Differential expression calculator" and statistic analysis - in Excel program. The amplified DNA fragments were separated on a $2 \%$ agarose gel and visualized by $5 x$ Sight DNA Stain (EUROMEDEA).

ISSN 1996-4536 • Біологічні Студії / Studia Biologica • 2011 • Том 5/№2 • С. 37-50 


\section{RESULTS}

In this study, we used human glioma cell line U87 and its genetically modified variant (with suppressed activity of signaling enzyme endoplasmic reticulum-nuclei-1) to investigate the involvement of endoplasmic reticulum stress system in the effect of hypoxia and ischemia (glutamine or glucose deprivation) on the expression of different genes of circadian clock. For this aim, the cells were incubated at $37^{\circ} \mathrm{C}$ before harvesting in regular DMEM medium (control) and in the medium without glucose or glutamine as well as regular DMEM medium in hypoxic conditions ( $3 \%$ oxygen) for 16 hours. The mRNA expression levels of different circadian genes were quantified by real time polymerase chain reaction of complementary DNA.

We have found that PER1, PER2, PER3, CLOCK, BMAL1, BMAL2, DEC2 and CRY1 mRNA are expressed in the human glioma cell line U87 and the level of its expression depends upon the signaling enzyme endoplasmic reticulum-nuclei-1 function in normal, hypoxic and ischemic conditions. As shown in fig. 2, the level of PER1 mRNA expression is increased more than two fold in glioma cells, deficient in signaling enzyme endoplasmic reticulum-nuclei-1, as compared to control cells. Exposure of glioma cells to hypoxia for 16 hours or to glutamine deprivation conditions leads to an increase in the level of PER1 mRNA expression, but only in control cells (+31 and $+16 \%$, correspondingly). At the same time cell exposure to glucose deprivation conditions leads to an increase of PER1 mRNA expression both in control and in genetically modified cells ( +25 and $+22 \%$, correspondingly).

The expression level of PER2 mRNA is decreased in glioma cells with suppressed activity of signaling enzyme endoplasmic reticulum-nuclei-1 in two fold as compared to control glioma cells (fig. 3). Effect of glucose or glutamine deprivation conditions on the expression level of PER2 mRNA was observed both in control $(+18$ and $+11 \%$, correspondingly) and genetically modified ( +36 and $+27 \%$, correspondingly) glioma cells been less significant in control cells. However, hypoxia reduces the expression level of PER2 mRNA in cells without endoplasmic reticulum-nuclei-1 activity and does not change it in control glioma cells (fig. 3).

As shown in fig. 4, the level of PER3 mRNA expression is increased (+69\%) in glioma cells with suppressed endoplasmic reticulum-nuclei-1 activity as compared to control glioma cells. Hypoxia significantly reduced expression of this mRNA level in both studied cell types, however glutamine deprivation condition did not change the expression level of PER3 mRNA both in control and genetically modified glioma cells. At the same time, the effect of glucose deprivation conditions on the expression of PER3 mRNA was different in control glioma cells $(+28 \%)$ and cells with suppressed activity of endoplasmic reticulum-nuclei-1 (-16\%) (fig. 4).

It was also shown that blockade of endoplasmic reticulum-nuclei-1 activity leads to decrease in the expression levels of BMAL1 (-20\%), BMAL2 (-50\%), CRY1 (-47\%) and DEC2 $(-41 \%)$ mRNA and to the increase of CLOCK (+43\%) mRNA levels (fig. $5-9)$. Glutamine deprivation condition lead to the increase of expression levels of BMAL1 and CRY1 mRNA and to the decrease of BMAL2 mRNA both in control and in endoplasmic reticulum-nuclei-1-deficient glioma cells. However, the expression levels of CLOCK and DEC2 mRNA do not change significantly in both cell types (fig. 7 and 9). At the same time, glucose deprivation condition increases the expression levels of BMAL1 and does not change the BMAL2 mRNA both in control and endoplasmic reticulum-nuclei-1-deficient glioma cells, but CLOCK, DEC2 and CRY1 mRNA expression levels are increased 


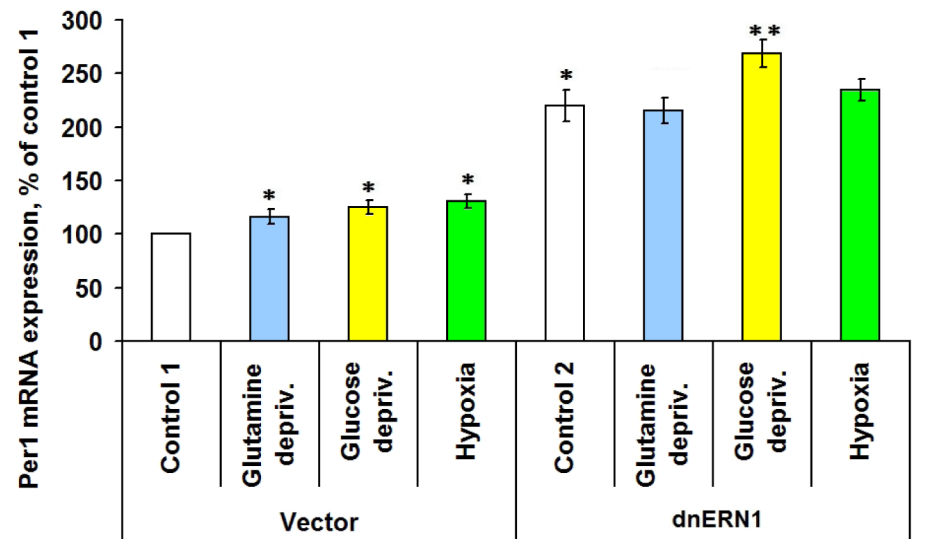

Fig. 2. Effect of hypoxia and glucose or glutamine deprivation on the expression of PER1 mRNA in glioma cell line U87 and its subline with knockdown of the signaling enzyme endoplasmic reticulum-nuclei-1 (dnERN1) measured by quantitative polymerase chain reaction. Values of PER1 mRNA expressions were normalized to the expression of beta-actin mRNA and represent as percent of control $1(100 \%)$; $\boldsymbol{n}=5 ;{ }^{*}-\mathrm{P}<0.05$ as compared to control $1 ;{ }^{* *}-\mathrm{P}<0.05$ as compared to control 2 . In fig. 2-9 control 1 represents glioma cells transfected with vector and control 2 - U87 glioma cells overexpressed dominant-negative construct of endoplasmic reticulum-nuclei-1

Рис. 2. Вплив гіпоксії та відсутності у середовищі глютаміну або глюкози на експресію мPHK PER1 у клітинах гліоми лінії U87 та її сублінії з пригніченою функцією сигнального ензиму ендоплазматичний ретикулум-ядро-1 (dnERN1) методом кількісної полімеразної ланцюгової реакції. Значення експресії мPHК PER1 нормалізували за експресією мРНК бета-актину і представляли у процентах відносно контролю $(100 \%) ; \boldsymbol{n}=5 ;{ }^{*}-\mathrm{P}<0,05$ порівняно з контролем 1 ; ** $-\mathrm{P}<0,05$ порівняно з контролем 2. На рис. 2-9 контроль 1 - це клітини гліоми, що були трансфековані вектором, а контроль 2 - клітини гліоми лінії U87 з надекспресією домінант-негативної конструкції ендоплазматичний ретикулум-ядро-1

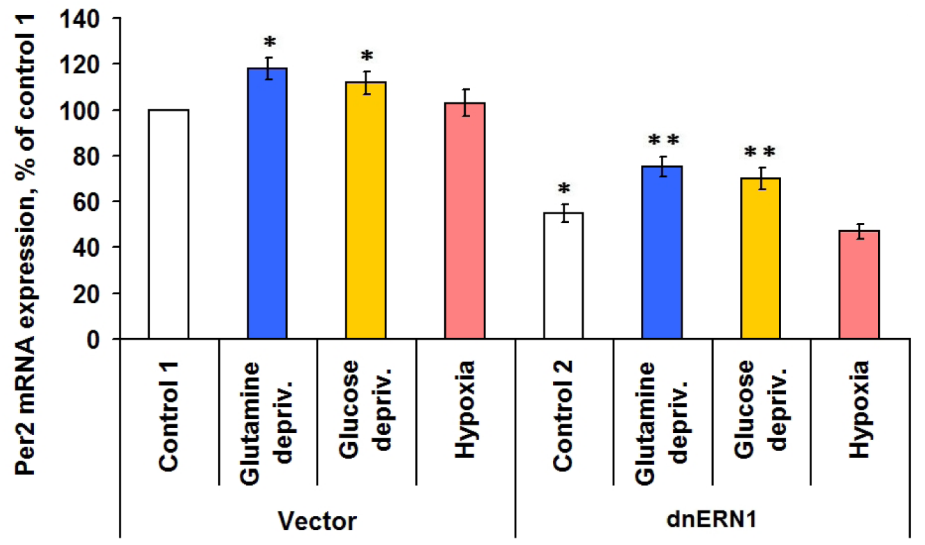

Fig. 3. Effect of hypoxia and glucose or glutamine deprivation on the expression of PER2 mRNA in glioma cell line U87 and its subline with knockdown of the signaling enzyme endoplasmic reticulum-nuclei-1 (dnERN1) measured by quantitative polymerase chain reaction. Values of PER2 mRNA expressions were normalized to the expression of beta-actin mRNA and represent as percent of control $(100 \%)$; $\boldsymbol{n}=5 ;{ }^{*}-\mathrm{P}<0.05$ as compared to control $1 ;{ }^{* *}-\mathrm{P}<0.05$ as compared to control 2

Рис. 3. Вплив гіпоксії та відсутності у середовищі глютаміну або глюкози на експресію мPHК PER2 у клітинах гліоми лінії U87 та іїі сублінії з пригніченою функцією сигнального ензиму ендоплазматичний ретикулум-ядро-1 (dnERN1) методом кількісної полімеразної ланцюгової реакції. Значення експресії MPHK PER2 нормалізували за експресією мРНК бета-актину і представляли у процентах відносно контролю (100 \%); $\boldsymbol{n}=5$; * $^{-\mathrm{P}<0,05}$ порівняно з контролем 1 ; ** $-\mathrm{P}<0,05$ порівняно з контролем 2 


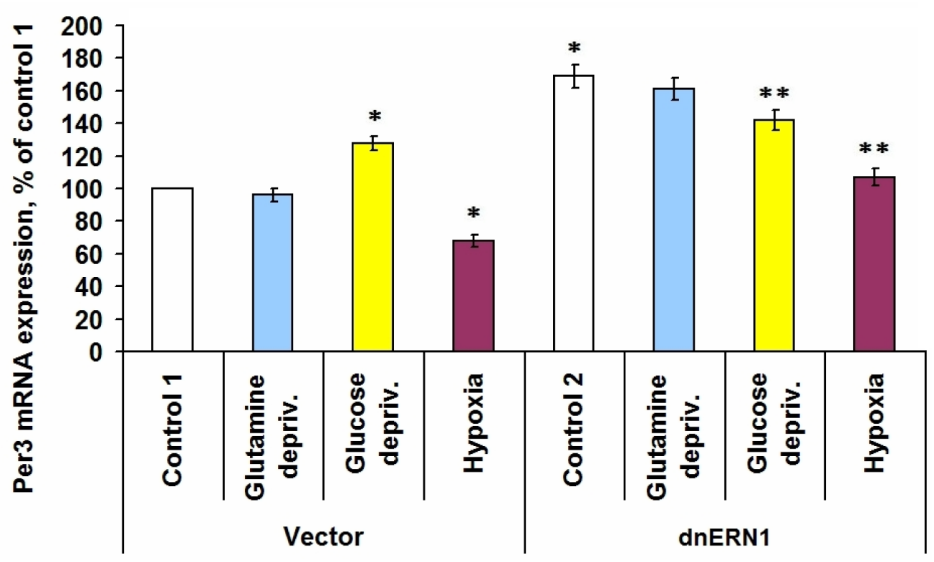

Fig. 4. Effect of hypoxia and glucose or glutamine deprivation on the expression of PER3 mRNA in glioma cell line U87 and its subline with knockdown of the signaling enzyme endoplasmic reticulum - nuclei-1 (dnERN1) measured by quantitative polymerase chain reaction. Values of PER3 mRNA expressions were normalized to the expression of beta-actin mRNA and represent as percent of control $(100 \%)$; $\boldsymbol{n}=5$; $^{*}-\mathrm{P}<0.05$ as compared to control 1 ; ${ }^{* *}-\mathrm{P}<0.05$ as compared to control 2

Рис. 4. Вплив гіпоксії та відсутності у середовищі глютаміну або глюкози на експресію мРHК PER3 у клітинах гліоми лінії U87 та її сублінії з пригніченою функцією сигнального ензиму ендоплазматичний ретикулум - ядро-1 (dnERN1) методом кількісної полімеразної ланцюгової реакції. Значення експресії мРНК РЕR3 нормалізували за експресією мРНК бета-актину і представляли у процентах відносно контролю $(100 \%) ; \boldsymbol{n}=5 ;$ * - P < 0,05 порівняно з контролем 1 ; ** - P $<0,05$ порівняно з контролем 2

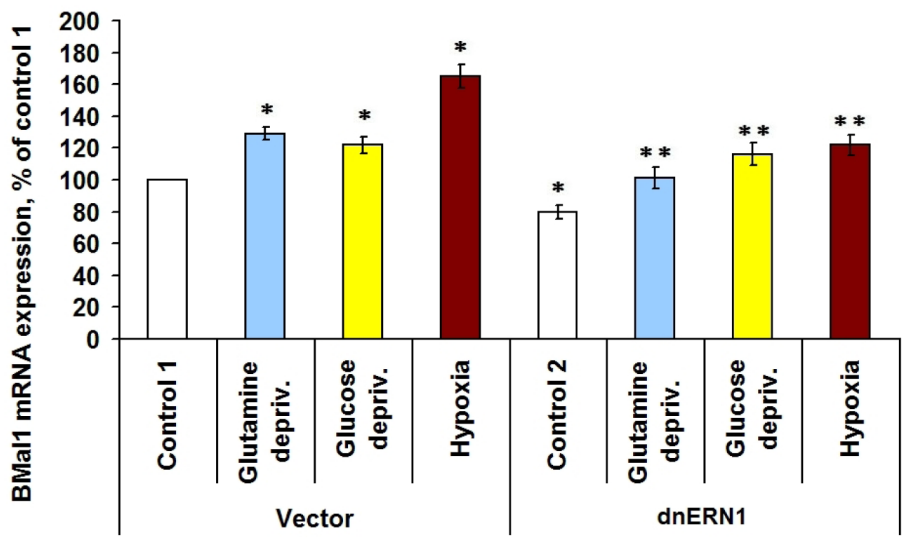

Fig. 5. Effect of hypoxia and glucose or glutamine deprivation on the expression of BMAL1 mRNA in glioma cell line U87 and its subline with knockdown of the signaling enzyme endoplasmic reticulum-nuclei-1 (dnERN1) measured by quantitative polymerase chain reaction. Values of BMAL1 mRNA expressions were normalized to the expression of beta-actin mRNA and represent as percent of control $(100 \%)$; $\boldsymbol{n}=5 ;{ }^{*}-\mathrm{P}<0.05$ as compared to control $1 ;{ }^{* *}-\mathrm{P}<0.05$ as compared to control 2

Рис. 5. Вплив гіпоксії та відсутності у середовищі глютаміну або глюкози на експресію мPHK BMAL1 у клітинах гліоми лінії U87 та її сублінії з пригніченою функцією сигнального ензиму ендоплазматичний ретикулум-ядро-1 (dnERN1) методом кількісної полімеразної ланцюгової реакції. Значення експресії мPHK BMAL1 нормалізували за експресією мPHК бета-актину і представляли у процентах відносно контролю $(100 \%) ; \boldsymbol{n}=5 ;$ * $-\mathrm{P}<0,05$ порівняно з контролем 1 ; ** $-\mathrm{P}<0,05$ порівняно з контролем 2 


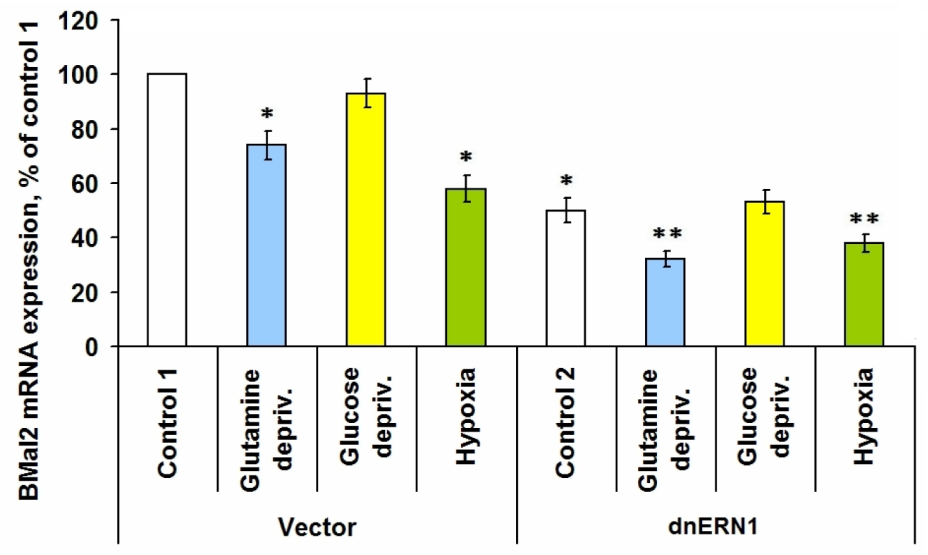

Fig. 6. Effect of hypoxia and glucose or glutamine deprivation on the expression of BMAL2 mRNA in glioma cell line U87 and its subline with knockdown of the signaling enzyme endoplasmic reticulum-nuclei-1 (dnERN1) measured by quantitative polymerase chain reaction. Values of BMAL2 mRNA expressions were normalized to the expression of beta-actin mRNA and represent as percent of control $(100 \%)$; $\boldsymbol{n}=5 ;{ }^{*}-\mathrm{P}<0.05$ as compared to control $1 ;{ }^{* *}-\mathrm{P}<0.05$ as compared to control 2

Рис. 6. Вплив гіпоксії та відсутності у середовищі глютаміну або глюкози на експресію MPHK BMAL2 у клітинах гліоми лінії U87 та її сублінії з пригніченою функцією сигнального ензиму ендоплазматичний ретикулум-ядро-1 (dnERN1) методом кількісної полімеразної ланцюгової реакції. Значення експресії мPHК BMAL2 нормалізували за експресією мРНК бета-актину і представляли у процентах відносно контролю $(100 \%) ; \boldsymbol{n}=5$; * - P $<0,05$ порівняно 3 контролем 1 ; ** $-\mathrm{P}<0,05$ порівняно з контролем 2

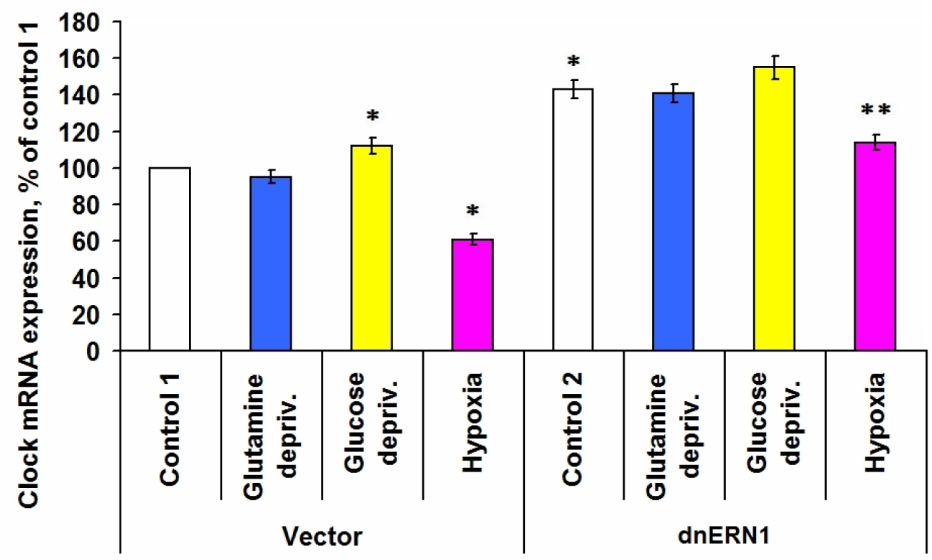

Fig. 7. Effect of hypoxia and glucose or glutamine deprivation on the expression of CLOCK mRNA in glioma cell line U87 and its subline with knockdown of the signaling enzyme endoplasmic reticulum-nuclei-1 (dnERN1) measured by quantitative polymerase chain reaction. Values of CLOCK mRNA expressions were normalized to the expression of beta-actin mRNA and represent as percent of control $(100 \%) ; \boldsymbol{n}=5 ;{ }^{*}-\mathrm{P}<0.05$ as compared to control $1 ;{ }^{* *}-\mathrm{P}<0.05$ as compared to control 2

Рис. 7. Вплив гіпоксії та відсутності у середовищі глютаміну або глюкози на експресію мРHK CLOCK у клітинах гліоми лінії U87 та її сублінії з пригніченою функцією сигнального ензиму ендоплазматичний ретикулум-ядро-1 (dnERN1) методом кількісної полімеразної ланцюгової реакції. Значення експресії мРНК CLOCK нормалізували за експресією мРНК бета-актину і представляли у процентах відносно контролю $(100 \%) ; \boldsymbol{n}=5 ;$ * - P < 0,05 порівняно 3 контролем 1 ; ** - Р $<0,05$ порівняно з контролем 2

ISSN 1996-4536 • Біологічні Студії / Studia Biologica • 2011 • Том 5/№2 • C. 37-50 


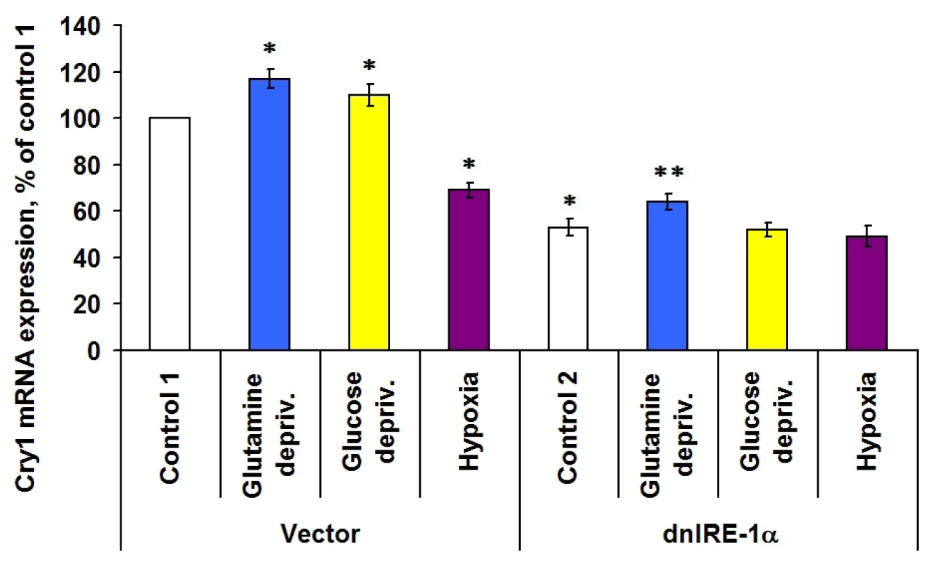

Fig. 8. Effect of hypoxia and glucose or glutamine deprivation on the expression of CRY1 mRNA in glioma cell line U87 and its subline with knockdown of the signaling enzyme endoplasmic reticulum - nuclei-1 (dnERN1) measured by quantitative polymerase chain reaction. Values of CRY1 mRNA expressions were normalized to the expression of beta-actin mRNA and represent as percent of control $(100 \%)$; $\boldsymbol{n}=5 ;{ }^{*}-\mathrm{P}<0.05$ as compared to control 1 ; ${ }^{* *}-\mathrm{P}<0.05$ as compared to control 2

Рис. 8. Вплив гіпоксії та відсутності у середовищі глютаміну або глюкози на експресію мРНК CRY1 у клітинах гліоми лінії U87 та її сублінії з пригніченою функцією сигнального ензиму ендоплазматичний ретикулум - ядро-1 (dnERN1) методом кількісної полімеразної ланцюгової реакції. Значення експресії мРНК CRY1 нормалізували по експресії мРНК бета-актину і представляли у процентах віднсно контролю (100\%); $\boldsymbol{n}=5$; * - P $<0,05$ порівняно з контролем 1 ; ** - P $<0,05$ порівняно з контролем 2

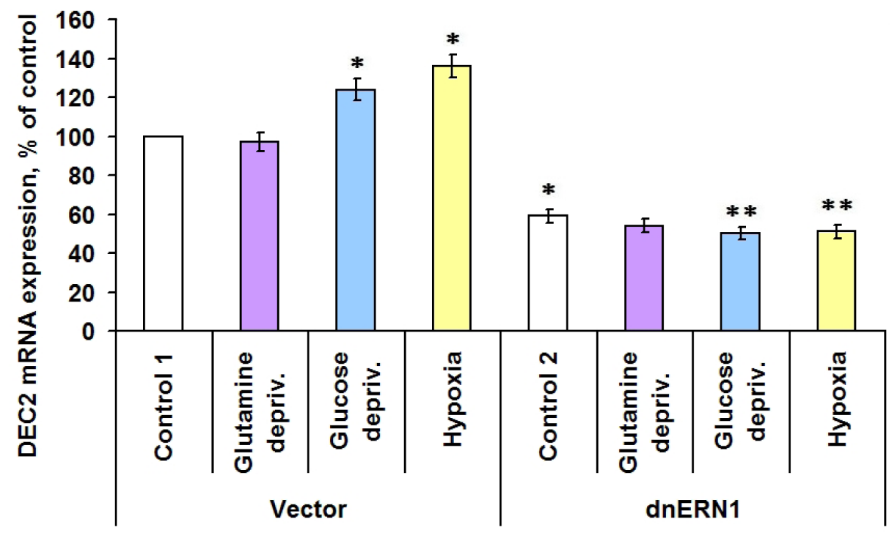

Fig. 9. Effect of hypoxia and glucose or glutamine deprivation on the expression of DEC2 mRNA in glioma cell line U87 and its subline with knockdown of the signaling enzyme endoplasmic reticulum-nuclei-1 (dnERN1) measured by quantitative polymerase chain reaction. Values of DEC2 mRNA expressions were normalized to the expression of beta-actin mRNA and represent as percent of control (100\%); $\boldsymbol{n}=5 ;{ }^{*}-\mathrm{P}<0.05$ as compared to control $1 ;{ }^{* *}-\mathrm{P}<0.05$ as compared to control 2

Рис. 9. Вплив гіпоксії та відсутності у середовищі глютаміну або глюкози на експресію мPHK DEC2 у клітинах гліоми лінії U87 та її сублінії з пригніченою функцією сигнального ензиму ендоплазматичний ретикулум-ядро-1 (dnERN1) методом кількісної полімеразної ланцюгової реакції. Значення експресії мРНК DEC2 нормалізували за експресією мРНК бета-актину і представляли у процентах відносно контролю (100\%); $\boldsymbol{n}=5 ;{ }^{*}-\mathrm{P}<0,05$ порівняно $з$ контролем 1; ** - P $<0,05$ порівняно з контролем 2 
in control glioma cells only. Hypoxia has different effects on the expression of BMAL1, BMAL2, CLOCK, DEC2 and CRY1 mRNA. As shown in fig. 5, hypoxia induces expression of BMAL 1 mRNA in both cell types: $+65 \%$ in control glioma cells and $+50 \%$ in endoplasmic reticulum-nuclei-1-deficient cells. The expression levels of BMAL2 and CLOCK mRNA are decreased in control glioma cells (-42 and $-39 \%$, correspondingly) as well as in cells with suppressed activity of endoplasmic reticulum-nuclei-1 (-24 and $-20 \%$, correspondingly) (fig. 6 and 7 ). As shown in fig. 8 and 9 , the effect of hypoxia on the expression of CRY1 and DEC2 depends upon endoplasmic reticulum-nuclei-1 function: hypoxia decreases the expression level of CRY1 mRNA (-31\%) in control glioma cells only; however, the level of DEC2 mRNA expression is increased in control cells $(+36 \%)$ and is decreased in genetically modified glioma cells $(-16 \%)$.

\section{DISCUSSION}

Highly aggressive brain tumor glioma forms from the malignization of astrocytes which are the most abundant cell types in the brain. They play an important role in the maintenance of neuronal functions. The molecular mechanisms underlying the uniquely aggressive behavior of these tumors have not yet been elucidated. In this study we investigate the effect of suppression of enzymatic activity of the main signaling system of endoplasmic reticulum stress on the expression of basic circadian factors which play a significant role in the control of main metabolic processes as well as proliferation process and malignant tumor growth in normoxic, hypoxic and ischemic conditions [9].

Our results clearly demonstrate that the expression pattern of the main circadian genes is controlled by the endoplasmic reticulum stress system which is hyper active in malignant tumors. We have shown that swiching off the endoplasmic reticulum stress in glioma cells by suppressing the activity of endoplasmic reticulum-nuclei-1, which is the major sensor and signaling system of this stress, changes the expression pattern of most circadian genes which, as known, are disregulated in malignant tumors. In glioma cells that lack the activity of the main endoplasmic reticulum stress signaling enzyme the expression level of PER1, which has strong tumor suppressor function, is significantly increased [5]. Its overexpression in cancer cells resulted in significant growth inhibition and apoptosis. This data correlates with suppression of glioma growth.

Endoplasmic reticulum stress changes the expression of hundreds of genes for the purpose of cellular adaptation to stress conditions and cell survival via the initiation of the pre-XBP1 mRNA splicing. Mature XBP1 mRNA encodes a transcription factor that stimulates the expression of unfolded protein response-specific genes. At the same time the expression of most of the endoplasmic reticulum stress-dependent genes is up-regulated, but there is a group of genes the expression of which is down-regulated $[9,17]$. Thus, the expression of pro-angiogenic factors IL-6, IL-8 and VEGF-A is downregulated and the expression of the anti-angiogenic factors SPARC, decorin, thrombospondin-1 and some other proteins functionally linked to mesenchymal differentiation (MYRL2, FHL1, COLL1A2) is up-regulated. Results of our investigastion have shown that the blockade of ERN1 leads to a change in the expression levels of circadian genes: Showing an increase in the expression levels of PER1, PER3 and CLOCK mRNA and a decrease the expression levels of CRY1, PER2, BMAL1, BMAL2 and DEC2 mRNA. It is known that in the circadian clock system there are strong interactions between different circadian factors with feedback mechanisms [4, 5].

ISSN 1996-4536 • Біологічні Студії / Studia Biologica • 2011 • Том 5/№2 • С. 37-50 
The circadian genes have the emerging role as key players in malignant transformation, because factors, encoded by these genes, participate in cell cycle control and tumor growth. Deregulated expression of circadian genes as well as inactivation or knockout of PER1, CLOCK and BMAL1 leads to malignization, especially in the breast, or the appearance of various disorders obesity in particular. A better understanding of the impact of circadian gene networks on cell cycle control as well as nutrient balance at the molecular, cellular and system levels promises to shed light on the emerging association between circadian timing and various medical conditions such as disorders of sleep, diabetes, obesity, and cancer [23, 24].

The rapid growth of different solid malignant tumors generates micro-environmental changes due to nutrient deprivation, hypoxia and acidosis. Under those ischemic conditions, cancer cells trigger an adaptive response and initiate the formation of new blood vessels inside the tumor which are needed for its proliferation [8]. Hypoxia and ischemia are the main factors necessary for tumor growth via induction of complex intracellular signaling events and endoplasmic reticulum stress [9]. We have shown that hypoxia as well as ischemia significantly changes the expression pattern of different circadian genes and that these changes are dependent on endoplasmic reticulum stress signaling, because complete blockade of the endoplasmic reticulum-nuclei-1 enzyme activity modifies the effect hypoxia and ischemia has on most circadian genes expression levels in control glioma cells.

Results of this investigation clearly demonstrate that the expression level of different circadian genes in glioma cells is regulated by hypoxic and ischemic conditions (glutamine or glucose deprivation) and significantly depends upon functional activity of the signaling enzyme endoplasmic reticulum-nuclei-1, the main sensor of endoplasmic reticulum stress. Thus, most circadian genes participate in endoplasmic reticulum stress signaling and in malignant tumor growth and the suppression of this signaling affects the expression pattern of circadian genes which correlates with the suppression of glioma growth.

1. Gonze D., Goldbeter A. Circadian rhythms and molecular noise. Chaos, 2006; 16(2): 026110 (1-11).

2. Hastings M.H., Maywood E.S., Reddy A.B. Two decades of circadian time. Journal of Neuroendocrinology, 2008; 20(6): 812-819.

3. Kovac J., Husse J., Oster H. A time to fast, a time to feast: the crosstalk between metabolism and the circadian clock. Molecules and Cells, 2009; 28(2): 75-80.

4. Pfeffer M., Muller C.M., Mordel J. et al. The mammalian molecular clockwork controls rhythmic expression of its own input pathway components. Journal of Neuroscience, 2009; 29(19): 6114-6123.

5. Карбовський Л.Л., Мінченко Д.О., Гармаш Я.А., Мінченко О.Г. Молекулярні механізми функціонування циркадіального годинника. Український біохімічний журнал, 2010; 83(3): 5-25.

6. Rudic R.D., McNamara P., Curtis A.M. et al. BMAL1 and CLOCK, two essential components of the circadian clock, are involved in glucose homeostasis. PLoS Biology, 2004; 2(11): E377.

7. Moenner M., Pluquet O., Bouchecareilh M., Chevet E. Integrated endoplasmic reticulum stress responses in cancer. Cancer Research, 2007; 67(22): 10631-10634.

8. Drogat B., Auguste P., Nguyen D.T. et al. IRE1 signaling is essential for ischemia-induced vascular endothelial growth factor-A expression and contributes to angiogenesis and tumor growth in vivo. Cancer Research, 2007; 67: 6700-6707. 
9. Auf G., Jabouille A., Guérit S. et al. A shift from an angiogenic to invasive phenotype induced in malignant glioma by inhibition of the unfolded protein response sensor IRE1. Proceedings of the National Academy of Sciences of the U.S.A., 2010; 107(35): 15553-15558.

10. Bi M., Naczki C., Koritzinsky M. et al. ER stress-regulated translation increases tolerance to extreme hypoxia and promotes tumor growth. EMBO Journal, 2005; 24(19): 3470-3481.

11. Blais J.D., Filipenko V., Bi M. et al. Transcription factor 4 is translationally regulated by hypoxic stress. Molecular and Cellular Biology, 2004; 24: 7469-7482.

12. Fels D.R., Koumenis $C$. The PERK/elF2a/ATF4 module of the UPR in hypoxia resistance and tumor growth. Cancer Biology \& Therapy, 2006; 5(7): 723-728.

13. Luo D., He Y., Zhang H., Yu L. et al. AIP1 is critical in transducing IRE1-mediated endoplasmic reticulums response. The Journal of Biological Chemistry, 2010; 285(18): $11905-11912$.

14. Korennykh A.V., Egea P.F., Korostelev A.A. et al. The unfolded protein response signals through high-order assembly of Ire1. Nature, 2009; 457(7230): 687-693.

15. Aragón T., van Anken E., Pincus D. et al. Messenger RNA targeting to endoplasmic reticulum stress signalling sites. Nature, 2009; 457(7230): 736-740.

16. Acosta-Alvear D., Zhou Y., Blais A. et al. XBP1 controls diverse cell type- and conditionspecific transcriptional regulatory networks. Molecular Cell, 2007; 27: 53-66.

17. Hollien J., Lin J.H., Li H. et al. Regulated Ire1-dependent decay of messenger RNAs in mammalian cells. Journal of Cell Biology, 2009; 186(3): 323-331.

18. Greenman C., Stephans $P$., Smith R. et al. Patterns of somatic mutation in human genomes. Nature, 2007; 446: 153-158.

19. Hunt T., Sassone-Corsi P. Riding tandem: Circadian clocks and the cell cycle. Cell, 2007; 129: 461-464.

20. Hua H., Wang Y., Wan C. et al. Circadian gene mPer2 overexpression induces cancer cell apoptosis. Cancer Science, 2006; 97: 589-596.

21. Cao Q., Gery S., Dashti A. et al. A role for the clock gene per1 in prostate cancer. Cancer Research, 2009; 69(19): 7619-7625.

22. Taniguchi H., Fernandez A.F., Setien F. et al. Epigenetic inactivation of the circadian clock gene BMAL1 in hematologic malignancies. Cancer Research, 2009; 69(21): 8447-8454.

23. Chen S. T., Choo K. B., Hou M. F. et al. Deregulated expression of the PER1, PER2 and PER3 genes in breast cancers. Carcinogenesis, 2005; 26(7): 1241-1246.

24. Climent J., Perez-Losada J., Quigley D.A. et al. Deletion of the PER3 gene on chromosome 1 p36 in recurrent ER-positive breast cancer. Journal of Clinical Oncology, 2010; 28(23): 3770-3778.

25. Ramsey K.M., Marcheva B., Kohsaka A., Bass J. The clockwork of metabolism. Annual Review of Nutrition, 2007; 27: 219-240.

\title{
ПРИГНІЧЕННЯ СИГНАЛЬНОГО ЕНЗИМУ ЕНДОПЛАЗМАТИЧНИЙ РЕТИКУЛУМ-ЯДРО-1 МОДИФІКУЄ ЕФЕКТ ГІПОКСІЇ ТА ІШЕМІЇ НА ЕКСПРЕСІЮ ЦИРКАДІАЛЬНИХ ГЕНІВ У КЛІТИНАХ ГЛІОМИ
}

\author{
Л. Л. Карбовський', Д. О. Мінченко ${ }^{1,2}$, \\ С. В. Даниловський', М. Моне ${ }^{3}$, О. Г. Мінченко ${ }^{1,3}$ \\ 1/нститут біохімії ім. О. В. Палладіна НАН України, вул. Леонтовича, 9, Київ 01601, Україна \\ ${ }^{2}$ Національний медичний університет ім. О. О. Богомольця, \\ бульв. Шевченка, 13, Київ 01601, Україна \\ 3INSERM U1029 Лабораторія молекулярних механізмів ангіогенезу \\ Університету Бордо, 1, Таленс, Франція \\ e-mail: ominchenko@yahoo.com
}

ISSN 1996-4536 • Біологічні Студії / Studia Biologica • 2011 • Том 5/№2 • С. 37-50 
Основними молекулярними компонентами системи циркадіального годинника $€$ протеїни, які відіграють суттєву роль у контролі як метаболізму, так і росту злоякісних пухлин. Стрес ендоплазматичного ретикулуму, як і гіпоксія та ішемія, є важливими фракторами неоваскуляризації та росту пухлин. Ми вивчали експресію циркадіальних генів у клітинах гліоми лінії U87 за умов блокади сенсорного і сигнального ензиму ендоплазматичний ретикулум-ядро-1 (ERN1). Встановлено, що блокада сигнального ензиму ERN1 приводить до збільшення рівнів експресії PER1, PER3 та CLOCK мPHК і зниження рівнів мPHK CRY1, PER2, BMAL1, BMAL2 і DEC2. Більше того, рівні експресії більшості із досліджуваних генів зростають за умов відсутності у середовищі глюкози або глютаміну як у контрольних, так і в дефріцитних за ензимом ERN1 клітинах гліоми, але пригнічення ERN1 модифікує ефект цих ішемічних умов. Гіпоксія має різні ефекти на рівні експресії циркадіальних генів, причому ці ефекти залежать від функції ERN1. Встановлено, що гіпоксія посилює експресію мPHK PER1, BMAL1 та DEC2 і знижує - PER3, CLOCK, CRY1 та BMAL2 в контрольних клітинах гліоми, а в генетично модифрікованих клітинах посилює експресію мPHK лише BMAL1. Таким чином, експресія циркадіальних генів залежить від функції сигнального ензиму ERN1 як за нормальних умов, так і за умов гіпоксії та ішемії.

Ключові слова: експресія мPHK, PER1, PER2, PER3, CLOCK, BMAL1, BMAL2, CRY1, DEC2, клітини гліоми, ендоплазматичний ретикулумядро-1, гіпоксія, відсутність глюкози або глютаміну.

\title{
УГНЕТЕНИЕ СИГНАЛЬНОГО ЭНЗИМА ЕНДОПЛАЗМАТИЧЕСКИЙ РЕТИКУЛУМ-ЯДРО-1 МОДИФИЦИРУЕТ ЭФФЕКТ ГИПОКСИИ И ИШЕМИИ НА ЭКСПРЕССИЮ ЦИРКАДИАЛЬНЫХ ГЕНОВ В КЛЕТКАХ ГЛИОМЫ
}

\author{
Л. Л. Карбовский', Д. А. Минченко,, \\ С. В. Даниловский \\ 1 Институт биохимии им. А.В. Палладина НАН Украины \\ ул. Леонтовича, 9, Киев 01601, Украина \\ ${ }^{2}$ Национальный медицинский университет им. А. А. Богомольца, \\ бульв. Шевченко, 13, Киев 01601, Украина \\ 3INSERM U1029 Лаборатория молекулярных механизмов ангиогенеза, \\ Университет Бордо, 1, Таленс, Франция \\ e-mail: ominchenko@yahoo.com
}

Основными молекулярными компонентами системы циркадиальных часов являются протеины, которые играют существенную роль в контроле как метаболизма, так и роста злокачественных опухолей. Стресс эндоплазматического ретикулума, как и гипоксия и ишемия, являются важными факторами неоваскуляризации и роста опухолей. Мы изучали экспрессию циркадиальных генов в клетках глиомы линии U87 в условиях блокады сенсорного и сигнального энзима эндоплазматический ретикулум-ядро-1 (ERN1). Установлено, что блокада сигнального энзима ERN1 приводит к увеличению уровней экспрессии PER1, PER3 и CLOCK мPHK и снижению уровней мPHK CRY1, PER2, BMAL1, BMAL2 и DEC2. Более того, уровни экспрессии большинства из исследованных генов увеличиваются при отсутствии 
в среде глюкозы или глютамина как в контрольных, так и в дефицитных по энзиму ERN1 клетках глиомы, но угнетение функции ERN1 модифицирует эффрект этих ишемических условий. Гипоксия оказывает различные эффекты на уровни экспрессии циркадиальных генов, причем эти эффекты зависят от функции ERN1. Установлено, что гипоксия усиливает экспрессию мPHK PER1, BMAL1 и DEC2 и снижает - PER3, CLOCK, CRY1 и BMAL2 в контрольных клетках глиомы, а в генетически модифицированных клетках усиливает экспрессию только MPHK BMAL1. Таким образом, экспрессия циркадиальных генов зависит от функции сигнального энзима ERN1 как в нормальных условиях, так и в условиях гипоксии и ишемии.

Ключевые слова: экспрессия MPHK PER1, PER2, PER3, CLOCK, BMAL1, BMAL2, CRY1, DEC2, клетки глиомы, гипоксия, эндоплазматический ретикулум-ядро-1, отсутствие глюкозы или глютамина в среде.

Одержано: 14.06.2011 